\author{
Signe Rix Berthelin \\ Norges teknisk-naturvitenskapelige universitet (NTNU)
}

DOI: http://dx.doi.org/10.5617/adno.8218

\title{
Samisk språk og tekst i norskdidaktikken - oppdagelse og opplevelse
}

\begin{abstract}
Sammendrag
Artikkelen presenterer et nytt undervisningsopplegg der norsklærerstudenter leser en autentisk tekst på sørsamisk og skaffer seg innblikk i grammatikken gjennom stillasbyggende oppgaver og den online tilgjengelige ordboka Nedtedigibaakoeh (u.å.). I løpet av en enkelt økt får studenten innblikk i språket og verktøy og metoder til å utforske samisk språkstruktur videre alene eller sammen med elever. Hverken studenter eller faglærer må kunne et samisk språk for å gjennomføre opplegget. Samisk språk er del av den felles kulturarv som skal forvaltes av nålevende og kommende generasjoner (Utdanningsdirektoratet, 2020a). I et språkfag som norsk er det relevant å tilby lærerstudentene innblikk i samisk språkstruktur så vel som språkpolitiske og sosiolingvistiske forhold. Det er generelt utfordringer med å implementere opplæring om samiske tema i lærerutdanningene (Olsen, Sollid \& Johansen, 2017), og uten samisk språkkompetanse kan det være særlig utfordrende å undervise om samisk språkstruktur. Denne artikkelen viser hvordan slike utfordringer kan møtes med et opplegg som vektlegger autentisitet, studentaktivitet og internalisert motivasjon (Ryan \& Deci, 2000). En gjennomføring i et førsteårsemne i norskdidaktikk viser at studentene mestrer oppgavene og opplever engasjement og inspirasjon i arbeidet med sørsamiske sangtekster. Med gode stillas kan man altså saktens jobbe med autentisk samisk tekst på samisk og la studentene oppdage samisk språkstruktur. Videre har opplegget grammatikkdidaktisk potensial: Studentene må bruke grammatikkunnskap og metaspråk aktivt for å forstå den samiske teksten og samarbeide i prosessen. Dette kan bidra til varig forståelse av grammatikkbegreper, fordi studentene anvender grammatikkunnskapen til å løse oppgaver i nye sammenhenger (Haugen, 2019; Kunnskapsdepartementet, 2015-2016).
\end{abstract}

Nøkkelord: samisk språk, samisk tekst, sørsamisk, norskdidaktikk, grammatikkdidaktikk

\section{Saami language and text in Norwegian teacher education - discovery and experience}

\begin{abstract}
The paper presents newly developed teaching materials that enable Norwegian teacher students to read an authentic text in South Saami and get acquainted with the grammar through scaffolding activities and the online dictionary Nedtedigibaakoeh (n.d.). Within a single session the students get an insight into the language and tools and methods for exploring the language further alone or together with pupils. The materials do not
\end{abstract}


presuppose proficiency in a Saami language. Saami languages are part of the cultural heritage that must be sustained by present and future generations (Utdanningsdirektoratet [Norwegian Directorate for Education and Training], 2020a). In a language subject like Norwegian, it is relevant to offer the students an insight into Saami language structure as well as language policy and sociolinguistic realities. There are challenges with implementing teaching on Saami topics in Norwegian teacher education in general (Olsen, Sollid \& Johansen, 2017), and without Saami language proficiency, it may be especially challenging to teach Saami language structure. The paper shows how these challenges can be met through teaching materials that emphasise authenticity, student activity and internal motivation (Ryan \& Deci, 2000). An execution in a first-year course in Norwegian didactics shows that the students master the tasks and they find the work on authentic South Saami song lyrics engaging and inspiring. With appropriate scaffolding, it is possible to work with Saami texts in Saami and let the students discover the structure of the language. Moreover, the materials have a grammar didactic potential: The students must actively use their knowledge about grammar and metalanguage in order to understand the Saami text and collaborate in the process. This can contribute to a sustained understanding of grammatical terms because the students apply their knowledge about grammar to solve new problems in new contexts (Haugen, 2019; Kunnskapsdepartementet [Ministry of Education and Research], 2015-2016).

Keywords: Saami language, Saami text, South Saami, Norwegian didactics, grammar didactics

\section{Innledning}

Alle skoler i Norge er forpliktet til å gi opplæring om samiske forhold (Opplæringsloven, 1998; Utdanningsdirektoratet, 2020a), og alle norske lærerutdanninger må derfor tilby studentene kunnskap om samiske tema. Til tross for at de fleste institusjoner ser viktigheten av opplæring om samiske tema, er det tydelige utfordringer med implementeringen (se Olsen, Sollid \& Johansen, 2017, s. 5-6). Denne artikkelen presenterer et opplegg som kan gi norsklærerstudenter uten samiske språkferdigheter et innblikk i sørsamisk språk og tekst i løpet av en enkelt undervisningsøkt. Opplegget er ment som et bidrag til å møte utfordringene med å implementere undervisning om samiske språk i lærerutdanningen. Det har blitt prøvd ut i lærerutdanningen ved NTNUs campus i Tråante (Trondheim) som ligger i den sørsamiske delen av Saepmie ${ }^{1}$, og fokuserer derfor på sørsamisk språk og tekst. Strukturen i opplegget er imidlertid overførbar til arbeid med andre samiske språk.

Opplegget går i korte trekk ut på at studentene oversetter en autentisk sørsamisk tekst til norsk og samarbeider om oppgaver som inviterer til å oppdage forskjeller mellom sørsamisk og norsk grammatikk. De skaffer seg innblikk i tekstene gjennom sørsamisk språk i stedet for å møte tekstene i oversettelse til majoritetsspråket, og det sørsamiske språket blir dermed synliggjort (jf. Wong \&

\footnotetext{
${ }^{1}$ Saepmie er det sørsamiske navnet for det området som heter Sápmi på nordsamisk og Sábme på lulesamisk.
} 
Solis, 2019). Studentene får oppleve å lese en tekst på samisk og oppdage at de selv kan skaffe seg innblikk i samisk språk ved å bruke generell kunnskap om grammatikk. Dette utløser et grammatikkdidaktisk potensial, fordi studenter uten samiskkompetanse er avhengige av kunnskap om grammatiske kategorier når de skal oversette fra sørsamisk og jobbe med oppgavene.

Artikkelen behandler primært følgende forskningsspørsmål: Hvordan kan lcererutdanningen gi norsklæererstudenter innblikk i samisk språk på en meningsfylt måte der de opplever mestring og motivasjon? Det andre spørsmålet er hvordan arbeid med samisk grammatikk kan styrke generelle grammatikkkunnskaper. Neste seksjon på hvilken plass samisk språk og tekst har i norsk lærerutdanning og skole for å identifisere noen ambisjoner for undervisning om samisk språk og grammatikkundervisning generelt. I den tredje seksjonen greies det ut om det teoretiske fundamentet for opplegget gjennom begrep som motivasjon, mestring, autonomi, autentisitet, dybdelæring og metaspråk. Opplegget om sørsamisk språk og tekst presenteres i den fjerde seksjonen. Det gis en konkret beskrivelse av arbeidsgangen i opplegget med illustrasjoner og eksempel fra en gjennomføring der førsteårsstudenter i norskdidaktikk jobbet med sangtekstene til Sjamma onne maana (Bull, 1997) og Marja Mortenssons (2017) sørsamiske versjon av Stuora várrie. Med utgangspunkt i tilbakemeldinger fra studentene og teorier om behov for mestring, autentisitet, autonomi og tilhørighet drøfter den femte seksjonen oppleggets evne til å gi en meningsfylt opplevelse med samisk språk og tekst. Den sjette seksjonen drøfter oppleggets grammatikkdidaktiske potensial, og den siste seksjonen konkluderer artikkelen og foreslår videre forskning og utviklingsarbeid.

\section{Samisk språk og grammatikk i norskdidaktikken}

Loven forplikter alle skoler i Norge til å gi elevene opplæring om samiske forhold (Opplæringsloven, 1998), og det er ikke bare snakk om en plikt. Som sametingsråd Mikkel Eskil Mikkelsen understeker, så har alle elever en rettighet til å få ta del i kunnskapen om det flerkulturelle samfunnet de lever i (Mikkelsen, 2019). En lærerutdanning må derfor gjøre alle studenter i stand til å ivareta opplæring om samiske forhold for alle elever (Olsen, Sollid \& Johansen, 2017, s. 12). ${ }^{2}$ I et språkfag som norsk er det særlig relevant å formidle kunnskap om samiske språkforhold og tekster.

Ifølge Læreplan i norsk skal elevene lese oversatte samiske tekster (Utdanningsdirektoratet, 2020b). Dette kan jo sies å være et rimelig mål, ettersom få elever i norsk skole kan lese på et samisk språk ${ }^{3}$; med en norsk oversettelse kan

\footnotetext{
${ }^{2}$ Dette er en del av 'Indigenous education’ (se f.eks. Ngai, Bæk \& Paulgaard, 2015; Olsen, Sollid \& Johansen, 2017).

${ }^{3}$ For utgreiinger om årsakene til denne situasjonen, se f.eks. Inga Mortensson i NRK (2013), Steinfjell (2014) og NOU (2016: 18).
} 
de forstå og få glede av teksten. Samiske språk er imidlertid en viktig del av det landet elevene bor i, og dette taler for at de må få møte samisk språk i løpet av skolegangen. Kunnskap om hvordan et språk er bygd opp bidrar til å forstå at også dette språket har et mønster, det er ikke tilfeldige rekker av lyder, men et system i likhet med andre språk. Videre er samiske språk en del av samisk kulturarv, og den overordnede delen av læreplanen fastslår at den samiske kulturarven er del av den norske kulturarven som skal forvaltes av nålevende og kommende generasjoner (Utdanningsdirektoratet, 2020a). Det er derfor ønskelig at elever i Norge får innblikk i samisk språkstruktur i tillegg til sosiolingvistiske og politiske språkforhold.

I Rammeplan for allmennlærerutdanningen (2003, s. 9) står det at studentene må bli kjent med urfolks historie, kultur og institusjoner, og at dette blant annet innebærer nordsamisk, lulesamisk og sørsamisk språk. Samisk språk er ikke nevnt eksplisitt i de gjeldende rammeplaner for lærerutdanningene, men kjennskap til kultur har neppe sluttet å innebære kjennskap til språk. Jeg argumenterer ikke for at det er lærerutdanningens jobb å gjøre norsklærerstudenter flytende i samisk, og det er heller ikke norsklærerens jobb å gjøre elevene flytende i samisk. ${ }^{4}$ Poenget mitt er at det kan være givende for alle elever i Norge å få et inntrykk av samiske språkstrukturer og dermed innsikt i ett av de språk som er knyttet til landet de bor i. Videre kan oppdagelsen av egne evner til å sette seg inn i samisk språkstruktur gi mot til å lære seg mer samisk ved en senere anledning. Av disse grunnene kan det være aktuelt for en norsklærerutdanning å gi studentene et innblikk i samisk språkstruktur og vise dem arbeidsmåter og verktøy som de kan bruke til å utforske samisk språk selv eller sammen med elevene sine.

Det er også aktuelt å drøfte ambisjonsnivået når det gjelder lærerstudenters møte med samisk tekst. De færreste lærerstudenter kan lese en samisk tekst på originalspråket, men spørsmålet er om de alltid må få utdelt en norsk oversettelse. Jeg ønsker på ingen måte å argumentere imot bruken av samiske tekster i oversettelse til norsk. Det jeg ønsker er å åpne muligheten for at studenter (og elever) også skal få oppleve samisk tekst gjennom samisk språk. I sin diskusjon av engelske oversettelser i en hawaiisk avis argumenterer Wong og Solis (2019) med henvisning til Benjamin Lee Whorf - for at den engelske oversettelsen får leseren til ubevisst å forstå verden gjennom en «habitual linguistic template provided by English». I likhet med andre koloniserte områder som f.eks. Aortearoa/New Zealand er lærebøker og undervisning gjerne utformet og iverksatt på majoritetssamfunnets premisser (Olsen, Sollid \& Johansen, 2017, s. 10). Når studenter møter samisk tekst gjennom norsk, foregår møtet via en norsk linse, mer presist en norskspråklig linse. Dette har både en symbolsk og en praktisk konsekvens. Den praktiske konsekvensen er at de ikke får oppleve teksten

\footnotetext{
${ }^{4}$ Samiske elever har rett til opplæring i samisk uansett hvor i landet de bor. Hvis det ikke er en lærer som kan gi opplæring i samisk, må skoleeier tilby elevene alternativer som f.eks. leirskoleopphold og fjernundervisning (Regjeringen, 2018). NOU (2016: 18, s. 129) foreslår en lovfesting av skoleeiers ansvar for å informere om disse rettighetene.
} 
gjennom en samisk «linguistic template» (jf. Wong \& Solis, 2019). Den symbolske konsekvensen er at de kan få inntrykk av at samisk språk er for utilgjengelig for dem. Opplegget i denne artikkelen er utviklet for å gi studenter mulighet for å oppleve samisk tekst gjennom samisk språk i tillegg til de allerede eksisterende muligheter for å lese samiske tekster i oversettelse til norsk. Og det er, som vi skal se, heldigvis mulig for norsklærerstudenter å lese en samisk tekst på originalspråket, når de får hensiktsmessige stillas. ${ }^{5}$

Lærere som ønsker å undervise om samisk språkstruktur kan få problemer med å finne egnet undervisningsmateriell. Noen lærebøker for grunnskolen inneholder samisk originaltekst i tillegg til den norske oversettelsen, men en tekst gir ikke av seg selv innblikk i hvordan et språk er bygd opp. Et viktig unntak er Nye Kontekst 8-10, som viser enkelte samiske gloser og informasjon om særtrekk ved (nord)samisk språk (Blichfeldt \& Heggem, 2014, s. 357-360). Nye Kontekst 8-10 inneholder også oppgaver hvor eleven skal lære seg litt samisk ved å lese noen setninger i boka og søke på internett etter uttaleregler. Dette er spennende oppgaver, men hverken informasjonen eller oppgaveinstruksen tilbyr innblikk i grammatikken på en måte som gir elevene reell mulighet for å utforske hvordan språket er bygd opp eller for å lære å si noe på samisk som de kunne ha lyst til å si. Det er med andre ord ikke noe stillas som tilbyr elevene en forståelse for samisk språkstruktur. Elevene blir dermed avhengige av at læreren kan veilede dem i utforskingen av språket. Opplegget som presenteres i denne artikkelen, muliggjør utforsking av samisk språk ved bruk av en digital ordbok og generell grammatikkkunnskap.

Som nevnt trenger lærerstudenter kunnskap om samisk språk. De trenger også en dyp forståelse for språk og grammatikk generelt. Flere studier finner at lærerstudenter ikke har solid grammatikkunnskap med seg når de begynner på studiet (se f.eks. Holmen, 2014), og at grammatikk kan oppleves som vanskelig (f.eks. Laake \& Eiesland, 2019). Solid kunnskap om grammatikk er imidlertid nødvendig for å kunne lære bort grammatikk til alle elever og støtte elever som strever med lesingen (Refsahl, 2007, s. 195-196). Det er nødvendig for å bli komfortabel med å undervise i grammatikk, og det er nødvendig for å kunne snakke ubesværet med elever om språk og tekst (jf. f.eks. Holmen, 2014; Haugen, 2019; Laake \& Eiesland, 2019). Til dette trengs et metaspråk, altså kompetanse i å bruke grammatiske termer til å analysere og snakke om tekst og språkstrukturer (se f.eks. Iversen, Otnes \& Solem, 2011, s. 19-20; Haugen 2019; Laake \& Eiesland, 2019). Det er derfor ønskelig å undersøke hvordan arbeid med samisk språk kan styrke studentenes grammatikkunnskap og kompetanse i å bruke grammatikkens metaspråk (jf. det andre forskningsspørsmålet i innledningsseksjonen).

\footnotetext{
5 ‘Stillas', eller stillasbygging, er, kort sagt, ulike typer støtte som gjør eleven/studenten i stand til å løse en oppgave som ellers ville ligget utenfor hennes kompetanseområde (se f.eks. Wood, Bruner \& Ross, 1976, s. 90).
} 


\section{Teoretisk fundament}

\section{Motivasjon gjennom autentisitet og mestring}

Spørsmålet er nå hvordan undervisningen kan gjøres på en måte så studentene får innblikk i samisk språk på en meningsfylt måte der de opplever mestring og motivasjon (jf. forskningsspørsmålet i innledningen). Denne delseksjonen ser på hvordan vi kan nærme oss dette spørsmålet ved å ha øye for ulike aspekt ved motivasjon, nemlig autentisitet og mestring.

Bottenvann (2017) påpeker at skrivemotivasjonen øker når skriveren opplever skrivesituasjonen som reell og autentisk. Utgangspunktet til Bottenvanns (2017) studie var derfor å øke skrivemotivasjonen hos studentene ved å sikre flere reelle lesere av tekstene deres. Et opplegg om samisk grammatikk kan gjerne designes over samme autentisitetslest. Utforsking av bøyingsparadigmer vil trolig virke lite autentisk; et bøyingsparadigme kan oppleves abstrakt og løsrevet fra virkeligheten hvis det jobbes med isolert. Videre kan det være vanskelig å overbevise norsklærerstudenter (eller andre) om at det er interessant eller nyttig å kunne bøye et sørsamisk verb. Oppgaven vil trolig kjennes mer autentisk hvis den innebærer bruk av grammatikkunnskap til å få innblikk i en sørsamisk tekst som studenten ellers ikke ville kunnet lese og forstå. Med andre ord får selve oppgaven et reelt formål, nemlig forståelse av en tekst.

Motivasjon spiller en avgjørende rolle for å sette i gang og opprettholde den kognitive aktiviteten i arbeidet med en oppgave, og utholdenhet og engasjement øker jo mer internalisert motivasjonen er (Ryan \& Deci, 2000, s. 60-61; se også Talleraas, 2019, s. 170, 174). Internalisert motivasjon henger sammen med tilfredsstillelse av menneskets behov for autonomi, tilhørighet og kompetanse/ mestring (Ryan \& Deci, 2000, s. 57-58). I forlengelse av dette bør det nevnes at intrinsisk motivasjon (intrinsic motivation), som er den mest internaliserte typen motivasjon, «[...] will occur only for activities that hold intrinsic interest for an individual - those that have the appeal of novelty, challenge, or aesthetic value for that individual» (Ryan \& Deci, 2000, s. 59-60). Dette bekrefter behovet for at det jobbes med en autentisk tekst med estetiske kvaliteter.

På den andre siden er det nødvendig å bruke passende utfordrende oppgaver og legge til rette for at studentene opplever kompetanse og mestring (Ryan \& Deci, 2000, s. 64). Dette kan skape konflikt med behovet for at teksten er autentisk og estetisk: forenklede pedagogiske tekster er mindre utfordrende, men har ikke nødvendigvis disse kvalitetene. Man kan imidlertid saktens arbeide med forholdsvis vanskelige tekster så lenge studentene får den nødvendige støtten til å mestre oppgaven (jf. Cummins, 2017, s. 57; se også Cummins, 1981). En mulighet er så klart å gi studentene en norsk oversettelse, men da er oversettelsen allerede gjort, og utfordringen og den genuine utforskingen av teksten forsvinner. Et annet problem er at studenten lett kan komme til å fokusere på den norske oversettelsen (jf. Wong \& Solis, 2019) og oppleve mindre behov for se på den sørsamiske originalteksten. Videre er det viktig å huske på at en norsk oversettelse ikke gir 
innblikk i hvilke ord i den sørsamiske teksten som betyr hva. Studenten vil derfor ikke få en følelse med det sørsamiske språket, fordi det forblir ugjennomsiktig. Utfordringen er derfor å finne et stillas som gjør studentene i stand til å oversette den sørsamiske teksten selv, og dette kan de gjøre ved å bruke Nedtedigibaakoeh (u.å.). Nedtedigibaakoeh er et gratis språkverktøy som gjør det mulig å søke i en sørsamisk-norsk ordbok på nettet. ${ }^{6}$ Som vi skal se i neste seksjon er det ikke nødvendig å ha kompetanse $\mathrm{i}$ et samisk språk for å kunne anvende Nedtedigibaakoeh. Det som imidlertid er nødvendig, er kunnskap om grammatiske kategorier (verb og substantiv) og fenomen som bøying.

Som nevnt knytter Ryan og Deci (2000) også behov for autonomi og tilhørighet til internalisert motivasjon. Jo mer individet opplever autonomi, altså at oppgaven eller aktiviteten tjener et formål som hun selv verdsetter, jo mer internalisert vil motivasjonen være (s. 62). Videre er folk gjerne mer villige til å utføre bestemte handlinger når de opplever at handlingene har en verdi for signifikante andre som de har eller ønsker å ha tilhørighet til. I en undervisningskontekst betyr det at den internaliserte motivasjonen øker når studentene eller elevene opplever at lærerne bryr seg om dem og respekterer dem (Ryan \& Deci, 2000, s. 64). Særlig tilhørighet kan umiddelbart virke til å ha mer å gjøre med gjennomføringen av undervisningen enn med oppleggets design. Men som vi skal se i delseksjonen om studentperspektiver og motivasjon, kan selve aktiveringsaspektet i oversettelsesoppgaven bidra til en opplevelse av det som Ryan \& Deci (2000) kaller tilhørighet, fordi studentene kjenner seg inkluderte.

\section{Grammatikkdidaktiske perspektiv}

Grammatikkundervisning bør, ifølge Haugen (2019), synliggjøre forbindelsen mellom det abstrakte systemet (grammatikken) og faktisk språkbruk (f.eks. i en tekst). Dette bidrar til en helhetlig forståelse av språk, fordi det gir en opplevelse av hvordan grammatiske mønstre og realiseringene av disse i tekst er to sider av samme sak. En slik tilnærming øker også læringsutbyttet gjennom dybdelæring (ibid.). Følgende stortingsmelding handler om hva dybdelæring er for elever, men det er ikke vanskelig å se for seg at det samme gjelder studenters dybdelæring:

Elevenes læringsutbytte øker når de gjennom dybdelæring utvikler en helhetlig forståelse av fag og ser sammenhengen mellom fag, samt greier å anvende det de har lært, til å løse problemer og oppgaver i nye sammenhenger.

(Kunnskapsdepartementet, 2015-2016, s. 14)

Det er altså grunn til å anta at studenter kan utvikle en dypere og mer varig forståelse for grammatikk ved å anvende det de har lært om grammatikk til å løse problemer og oppgaver i arbeid med tekst.

Det er imidlertid ikke gitt at arbeid med norskspråklig tekst automatisk får studentene til å bruke metaspråk og viten om grammatiske kategorier. Når

\footnotetext{
${ }^{6}$ Nedtedigibaakoeh (u.å.) er også tilgjengelig for andre språk, heriblant nordsamisk-norsk, nordsamisk-finsk og enaresamisk-nordsamisk.
} 
norsklærerstudenter jobber med analyse av norske setninger kan de i noen grad støtte seg på intuisjon om hva som høres riktig ut på norsk. Det betyr naturligvis ikke at intuisjon er tilstrekkelig for å gjennomføre en reell setningsanalyse, men hvis setningen er på et språk man behersker godt, så går det likevel an å si noe om den uten å bruke grammatikkens metaspråk. Holmen (2014) presenterer et utdrag fra en gruppe studenters samtale om en syntaksoppgave. Oppgaven går ut på å finne ut hvorfor følgende ikke er korrekt: «Sånn er det og det ikke kommer til å forandre seg.» I såkalt standardnorsk skal adverbialet i en helsetning (i dette tilfellet ikke) stå etter det finitte verbalet (i dette tilfellet kommer). Studentene på gruppen klarer fint å finne ut hvordan ytringen skulle vært for å være korrekt, men de klarer ikke å forklare hvorfor ikke skal stå etter kommer (2014, s. 94-95). Studentene klarer altså å si noe om ytringen fordi de vet hva som høres riktig ut på standardnorsk. Dersom analyseobjektet er et språk som studentene ikke har intuisjoner om, så kommer de ikke noen vei uten å nyttiggjøre seg av kunnskap om grammatikk.

Et opplegg om sørsamisk grammatikk kan skape en situasjon der studentene må anvende kunnskap om grammatiske kategorier aktivt, fordi denne viten er nødvendig for å få innblikk i teksten. Hvis det legges opp til samarbeid, kan studentene samtidig få anledning til å øve på å bruke metaspråk i samtaler om språk og tekst.

\section{Et opplegg om sørsamisk språk og tekst}

Denne seksjonen beskriver opplegget 'Sørsamisk språk og tekst'. Mer spesifikt ser vi på materiellet og arbeidsgangen. Seksjonen inneholder eksempel fra en gjennomføring av opplegget på et førstesemesteremne i norskdidaktikk i det femårige masterprogrammet Grunnskolelærerutdanning 5.-10. trinn. Dette er for å vise konkret hvordan bruken av opplegget kan se ut i praksis, og for bedre å kunne drøfte hvilke andre aspekt enn selve opplegget som kan bidra til å motivere studentene i arbeidet med oppgavene.

\section{Undervisningskontekst og materiell}

Opplegget er utviklet i Tråante (Trondheim), som ligger i den sørsamiske delen av Saepmie. Det er derfor i første omgang laget for å gi studenter innblikk i sørsamisk språk og tekst. En annen grunn til å sørge for ressurser som tilbyr innblikk i nettopp sørsamisk språk, er at det er færre muligheter for å lære om sørsamisk enn for eksempel om nordsamisk (jf. f.eks. Blichfeldt \& Heggems (2014, s. 357-360) fokus på nordsamisk) som generelt har en sterkere posisjon (Gjerpe, 2017, s. 158; NOU 2016: 18, s. 73). Nedtedigibaakoeh (u.å.) er imidlertid tilgjengelig for flere språk, noe som gjør det enkelt å lage et liknende opplegg til arbeid med nordsamisk eller lulesamisk språk og tekst. 
Opplegget ble gjennomført av to faglærere (artikkelens forfatter og en kollega ${ }^{7}$ ) og sirka 35 studenter i begynnelsen av oktober 2019. Studentene hadde på det tidspunkt hatt sirka 10 undervisningsøkter i norskdidaktikk i studiet. Halvdelen av disse øktene hadde tatt for seg språk, hovedsakelig grammatikk. Det er derfor rimelig å anta at studentene hadde forholdsvis ferske erindringer om hvordan f.eks. verbbøying ser ut i norsk, som de kunne overføre og anvende i møtet med verbbøying i sørsamisk.

Hverken jeg eller min kollega kan sørsamisk, men vi er begge språkvitere. Vi hadde derfor god mulighet for å veilede studentene i arbeidet med oversettelsen og oppgavene, og vi kunne modellere bruk av metaspråk i samtalene. Forut for økten hadde jeg oversatt og glosset to sørsamiske tekster ved hjelp av Nedtedigibaakoeh, altså notert under hvert enkelt sørsamiske ord hva det betyr og hva morfemene i ordet betyr. Dette fungerte som lærerens ark, og ble ikke vist til studentene. Jeg hadde også notert forslag til svar på oppgavene samt veiledende spørsmål som faglærer kan stille studenter som sitter fast på en oppgave (se 'Lærerens ark' i Undervisningsmateriell, 2021).

De sørsamiske tekstene var barnesangen Sjamma onne maana (Bull, 1997) og Mortenssons (2017) sørsamiske versjon av Stuora várrie. ${ }^{8}$ Stuora várrie er tradisjonelt på umesamisk. Å lese Stuora várrie på sørsamisk er derfor ikke å lese en tekst på originalspråket. Å jobbe med denne teksten lar imidlertid studentene oppdage at umesamisk og sørsamisk er forskjellige språk (se oppgave 2 og 6 i 'Lærerens ark til Stuora várrie' i Undervisningsmateriell, 2021, og siste del av avslutningsseksjonen nedenfor). I tillegg er Stuora várrie særdeles vakker og en estetisk opplevelse, noe som har en verdi i seg selv og som motivasjon (jf. seksjonen «Teoretisk fundament» ovenfor).

\section{Arbeid med opplegget}

Økten varte sirka to og en halv time. Den begynte med en 45 minutters forelesning som problematiserte mangelen på viten om samiske tema i skolen, på lærerutdanninger og i samfunnet. Vi adresserte fornorskingen og konsekvensene av denne, og min kollega påpekte at selv om en ikke-samisk lærer kan oppleve berøringsangst, så bør hun ikke bidra til usynliggjøringen av det samiske ved å unngå å jobbe med samiske tema. Vi tydeliggjorde at som lærere i Norge får studentene et samfunnsansvar som innebærer å gi elevene kunnskap om samisk språk og kultur, og jeg delte min egen frustrasjon over fraværet av relevant kunnskap om Grønland i løpet av min skolegang i Danmark. Jeg fortalte dem om situasjoner der det var pinlig å være en danske uten viten om Grønland og oppfordret dem til å sørge for at deres fremtidige elever ikke skulle forlate skolen uten kunnskap om samisk språk, kultur og historie.

Forelesningen problematiserte også at læringsmål i den nye Læreplan i norsk (jf. seksjonen om samisk språk og grammatikk i norskdidaktikken; Utdannings-

\footnotetext{
${ }^{7}$ Mange takk til Ina Myrvang Nilsen for godt undervisningssamarbeid!

${ }^{8}$ Tekstene finnes via henholdsvis Sametinget (u.å.) og Mortensson (u.å.). Fremføringer er tilgjengelige på Spotify.
} 
direktoratet, 2020b) ikke er så ambisiøse når det kommer til samisk språk, og vi formidlet vårt ønske om at de skulle få innsikt i samisk språkstruktur ved å jobbe med opplegget. Det var spesielt gøy å fortelle studentene følgende: «Når dere går herfra i dag, så har dere lest en tekst på sørsamisk.» Vi fortalte at vi ikke ga dem norske oversettelser av sangtekstene, ettersom de skulle få kjenne på teksten på sørsamisk og det sørsamiske språket. Vi forklarte at oversettelser ikke viser hva de enkelte ordene betyr og ga følgende eksempel: Selv om oversettelsen 'nå skal du sove' hadde stått nedenunder setningen dellie edtjh åeredh, ville de ikke kunne se hvilke ord i den sørsamiske setningen som betyr 'du', 'sove' osv. ${ }^{9}$ Hvis man virkelig vil inn i teksten - og etterpå kunne høre når sangeren synger hva - så må man gjøre jobben selv.

Studentene fikk utdelt word-dokumenter med de to tekstene elektronisk via emnets intranett (se eksempel i Bilde 1). Det er god plass til å notere under hvert enkelt ord. Studentene ble delt i grupper. Noen grupper skulle jobbe med 'Sjamma onne maana', og noen grupper skulle jobbe med 'Stuora várrie'. Studentene fikk vite at de etterpå skulle presentere teksten sin for en student som hadde jobbet med den andre teksten og dertil hørende oppgaver, og vice versa. På denne måten ble alle i gruppen ansvarliggjorte fordi de måtte presentere det gruppen fant ut for noen som ikke hadde jobbet med samme tekst og oppgaver. Deretter fikk studentene se Nedtedigibaakoeh. En av flere fordeler ved Nedtedigibaakoeh er at man ikke trenger å vite hva grunnformen av ordet er for å kunne slå det opp. I Nedtedigibaakoeh kan man slå opp et hvilket som helst ord og få vite hva det betyr og hvordan det er bøyd. La oss se på et eksempel.

Bilde 1. Studentens ark

\begin{tabular}{|lccc|}
\hline \multicolumn{2}{|c|}{ Sjamma onne maana (2. vers) } & & \\
Sjamma, sjamma! & maana & \\
Sjamma & onne & åeredh. & \\
dellie & edtjh & luvnie & lea. \\
Aehtjie & bovtsi & & \\
& & maana. & \\
Sjamma & onne & & \\
\hline
\end{tabular}

\footnotetext{
${ }^{9}$ En leser som vet at mange språk bøyer verb i person, vil kanskje gjette at setningen inneholder et personbøyd verb, ettersom det er tre ord i den sørsamiske setningen og fire ord i den norske. Hun ville derfor kunne gjette at ett av de sørsamiske ordene uttrykker de to betydningene 'du' og 'skal'. Hun kan imidlertid ikke vite hvilket av de sørsamiske ordene som betyr 'du skal'.
} 
Bilde 2. Utdrag fra studentens ark

\begin{tabular}{|lll|}
\hline $\begin{array}{l}\text { dellie } \\
\text { derpå/så }\end{array}$ & $\begin{array}{l}\text { edtjh } \\
\text { du skal }\end{array}$ & $\begin{array}{l}\text { åeredh. } \\
\text { sove }\end{array}$ \\
\hline
\end{tabular}

Sjamma onne maana inneholder setningen dellie edtjh åeredh (linje 3 i Bilde 1). Det er enkelt å slå opp det første ordet dellie; det betyr 'da/derpå/så’, og det krever ingen grammatikkunnskaper å finne betydningen, ettersom det ikke er et bøyelig ord. Studenten slår opp ordet og noterer betydningen under dellie (se Bilde 2). Edtjh 'du skal' er derimot et verb, så det forekommer i ulike bøyinger. Edtjh er bøyd i andre person entall ('du'), men det vet en leser uten kompetanse i sørsamisk ikke. Hun vet heller ikke at det er et verb, og slett ikke hvordan infinitivformen ser ut. Denne kunnskapen er heller ikke nødvendig for å kunne slå opp edtjh i Nedtedigibaakoeh. Alt studenten trenger å gjøre er å skrive eller sette inn ordet slik det står i teksten i søkefeltet (se rød sirkel i Bilde 3) og trykke på søk. Da vil studenten få vite at det er et verb som betyr 'skulle'.

Bilde 3. Skjermbilde fra Nedtedigibaakoeh (u.å.)

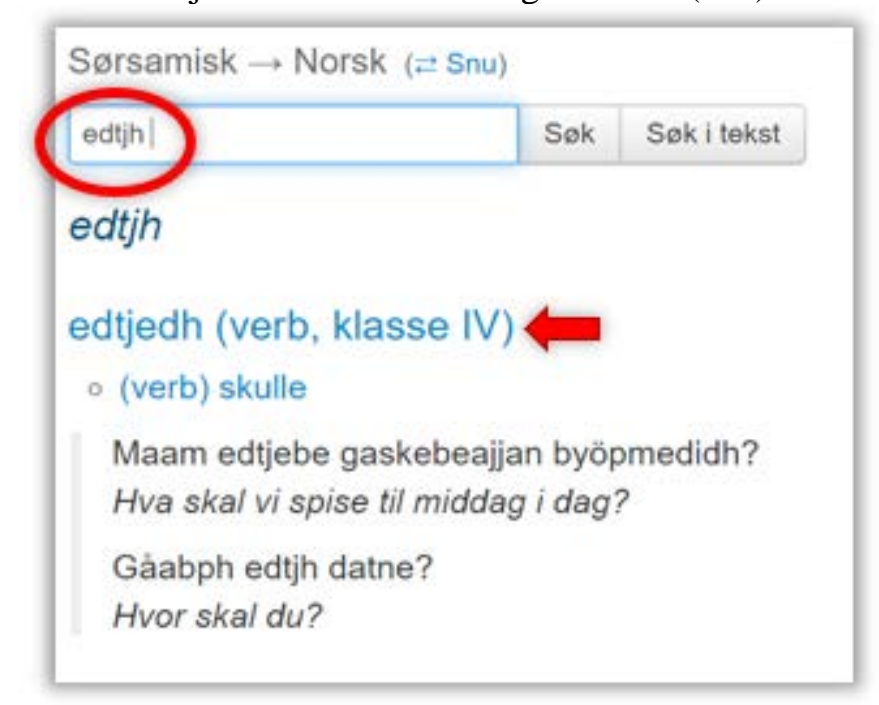

Neste steg er å finne ut hvem som 'skal' noe og når. Det finner man ut ved å trykke på det sørsamiske verbet i ordboksoppslaget (se rød pil i Bilde 3) og finne formen som forekommer i teksten, altså edtjh, i bøyingsoversikten (se Bilde 4). Da oppdager man at edtjh er andre person entall presens, altså 'du skal'. Studenten kan nå skrive 'du skal' under edtjh i arket sitt (se Bilde 2). Etterpå slår hun opp åeredh og noterer 'sove' i arket sitt. Nå har studenten betydningene til alle ordene i setningen, og hun kan lage en idiomatisk norsk oversettelse av setningen, for eksempel 'nå skal du sove'. ${ }^{10}$

\footnotetext{
${ }^{10}$ Som det fremgår lengre nede i Bilde 4, kan edtjh også være en nektingsform, så her er det aktuelt å gjøre studentene oppmerksomme på å se på konteksten når de avgjør hvilken betydning ordet uttrykker i teksten.
} 
Bilde 4. Skjermbilde fra Nedtedigibaakoeh (u.å.)

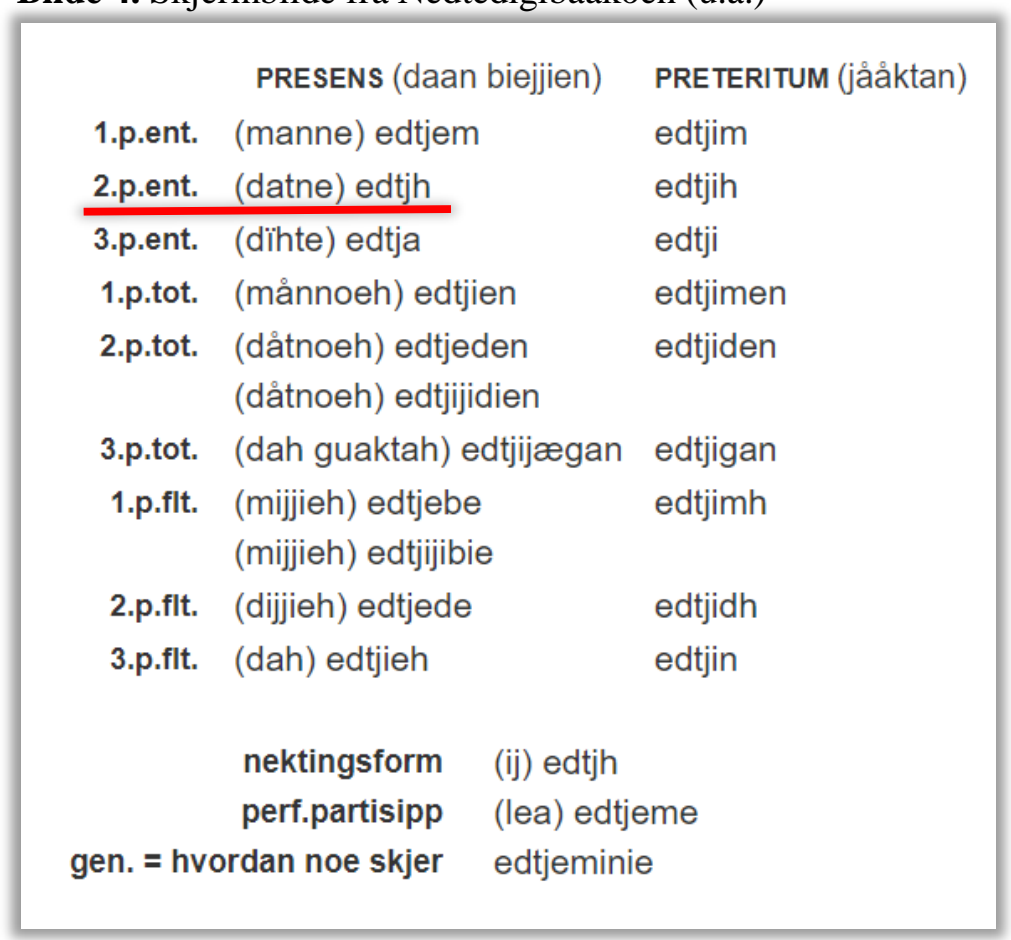

Kunnskap om sørsamisk grammatikk er dermed ikke nødvendig for å lage oversettelsen. Generell kunnskap om grammatikk er imidlertid nødvendig for å vite at dersom et ord er et verb, så må man klikke seg videre og finne ut hvilken tid det står i. Selv om studentene har kunnskap om grammatikk, så er det viktig å minne dem på at det ikke holder å finne ut hva ordene betyr for å forstå teksten - man må også se på bøying for å finne ut når handlingene foregår, og hvem som gjør hva med hvem. Arbeidsgangen kan gjerne modelleres med eksempelsetninger der studentene samklikker (Marion G. Stavsøien, personlig kommunikasjon, 2020). Faglærer bør også forklare alle forkortelsene som er brukt i ordboka (se venstre kolonne i Bilde 4). Selv om man vet at andre person entall svarer til 'du', så er det ikke gitt at man kopler denne viten til betegnelsen '2.p.ent.' i Nedtedigibaakoeh.

Arbeidsoppgavene etter oversettelsesarbeidet inviterer til å dykke dypere ned i sørsamisk grammatikk. En av oppgavene er å finne ut hvordan man sier 'nå skal jeg sove' og 'nå skal vi sove' på sørsamisk. I arbeidet med oversettelsen har studentene sett at dellie edtjh åeredh betyr 'nå skal du sove', så alt de trenger gjøre er å bytte edtjh 'du skal' ut med samme verb bøyd i førsteperson entall, i dette tilfellet edtjem 'jeg skal'. Det gjør de ved å lete i bøyingsoversikten (se Bilde 4).

I undervisningsøkten støttet faglærerne studentene i arbeidet med å finne ordenes bøying. Min kollega fikk blant annet en gruppe studenter til å bruke kunnskap om andre språk da de satt fast fordi de ikke husket hva personbøying var. Norske verb er ikke bøyd i person, så kunnskap om personbøying lå i beste fall langt tilbake i minnet. Engelske verb er derimot bøyd i person. Da hun henledet deres oppmerksomhet på personbøying i engelsk, gikk det et lys opp for dem som gjorde at de kunne løse oppgaven. De fikk samtidig oppleve at kunnskap om andre språk kan brukes når man møter et språk man ikke kan (ennå). Den 
individuelle oppfølgingen ga også rom for undrende spørsmål om språk. Jeg hadde blant annet en samtale med en gruppe studenter om at 'og' kan utelates på sørsamisk (jf. Magga \& Magga, 2012, s. 90) med utgangspunkt i deres oppdagelse av at det ikke er noe 'og' mellom aaltoeh 'reinkalver' og miesieh 'simler' i teksten til 'Stuora várrie'. Dette utviklet seg til en samtale om at en betydning uttrykkes språklig i noen språk, mens man i andre språk kan velge å kommunisere samme betydning implisitt. En annen samtale utsprang av studentenes undring over at kraesieh 'gress' er bøyd i flertall i 'Stuora várrie' mens gress er et massenomen på norsk. Dette ga anledning til å oppdage at ord med samme betydning kan være et massenomen på ett språk og et tellelig nomen på et annet språk.

\section{Opplegget som en vei til innblikk i sørsamisk språk og tekst}

Denne seksjonen drøfter hvordan opplegget oppfyller ønsket om å gi studenter uten samiske språkferdigheter innblikk i sørsamisk språk og tekst på en engasjerende og motiverende måte. Drøftingen tar utgangspunkt i tilbakemeldinger fra studentene og knytter disse til de teoretiske begrepene som ble introdusert i den første delen av seksjonen Teoretisk fundament. Først ser vi på hvordan oppleggets design og gjennomføring kan styrke studentenes motivasjon. Deretter diskuteres de anvendte stillasenes evne til å gi studentene føling med samisk språk og forståelse av de forholdsvis utfordrende sørsamiske tekstene.

\section{Studentperspektiver og motivasjon}

Etter økten ba vi studentene gi oss anonyme skriftlige tilbakemeldinger via en digital plattform der de ble de spurt om følgende: 1) Hva tar du med deg fra dagens øtt? 2) Hva fungerte bra? Hva var gøy/spennende? 3) Hva fungerte ikke så bra? 4) Hva kunne gjerne vært annerledes? 5) Annet du har lyst å si? Det var to svarkolonner for hvert spørsmål, en grønn og en gul. Studentene fikk instruks om å bruke grønne kolonner hvis de ville tillate bruk av tilbakemeldingene i forskning og rapportering. De gule kolonnene kunne brukes til å gi tilbakemeldinger uten å samtykke til bruk i forskning og rapportering. Langt de fleste svarte i de grønne kolonnene.

Studentene viste stor entusiasme i tilbakemeldingene. De ga uttrykk for at de hadde fått nye perspektiver, nye input og ny kunnskap om samiske tema. Noen meddelte at de hadde fått helt ny kunnskap om et totalt ukjent språk. Det virker altså som om opplegget oppfylte ønsket om å gi studentene innblikk i sørsamisk språk. Det ble også bemerket at det var gøy, og at musikk og kultur er en fin måte å angripe tekst på. Opplegget ser derfor ut til å ha noen element av estetikk og nyskaping, som er nødvendig for å oppleve den mest internaliserte formen for motivasjon (Ryan \& Deci, 2000, s. 59-60).

Studentene svarte at de likte at de fikk jobbe med praktiske oppgaver der de selv kunne utforske språket, og at det var spennende å oversette ord selv. Noen 
bemerket at de hadde fått nye tanker om hvordan de selv kan trekke inn samisk språk i egen undervisning på ungdomstrinnet, og noen påpekte at opplegget kan tilpasses til bruk på ungdomstrinnet. Det ser altså ut til at opplegget har tilfredsstilt behovet for autonomi som er en av de viktige driverne i internalisert motiverte handlinger (Ryan \& Deci, 2000, s. 62; Talleraas, 2019, s. 172). Fordi studentene opplevde at arbeidet med opplegget ga dem perspektiver og inspirasjon til egen fremtidig yrkesutøvelse, er det rimelig å anta at de har opplevd arbeidet med oppgavene som givende i seg selv, det vil si at de har sett en nytte av arbeidet som går ut over faglærers krav om å gjøre oppgavene.

Et annet poeng som er verdt å drøfte i forbindelse med motivasjon, har å gjøre med innrammingen av opplegget. Innrammingen kan nemlig tenkes å spille en rolle for hvordan studentene opplevde relevansen av arbeidsoppgavene. Vi begynte som nevnt økten med en kritisk innføring i læreplanens kompetansemål om samiske tema. En student bemerket i tilbakemeldingen at min erfaringsdeling som danske med manglende kunnskap om Grønland, var spennende. Hvis erfaringsdelingen har engasjert, er det mulig at den har styrket studentenes opplevelse av at den kunnskapen de ville få gjennom arbeidet med opplegget tjener et mål som de ønsker å nå, noe som styrker opplevelsen av autonomi og dermed internalisert motivasjon. En annen student bemerket at hun blant annet satt igjen med «et ønske om å gi elevene mine muligheten til å utforske samisk kultur fortløpende gjennom året», og en bemerket at hun «ble inspirert og motivert og ser mer positivt på det å inkludere det samiske i egen framtidige undervisning». Slike tilbakemeldingene tyder på at studentene opplevde opplegget som relevant for fremtidig yrkespraksis. I tillegg kan det tenkes å styrke den internaliserte motivasjonen gjennom opplevelse av tilhørighet, fordi det ble tydeliggjort at deres kunnskap om samisk språk har en verdi for deres fremtidige elever, og at vi faglærere bryr oss om at de og elevene deres får kunnskap om samisk språk.

Det ser også ut til at selve oppgavene har tilfredsstilt behov for tilhørighet. Noen studenter skrev at de kjente seg inkluderte i undervisningen og at det var fint å få utforske språket selv. Dette indikerer at de har følt seg som en del av et utforskende fellesskap. Flere av studentene meddelte også at de opplevde faglærerne som engasjerte og morsomme, og at energien vår smittet over på dem. Min kollega og jeg er genuint interesserte i grammatikk, sosiolingvistikk og språkpolitikk, så vi var naturligvis glade for å kunne dele disse interessene med studentene våre. Det utforskende fellesskapet ble også styrket gjennom de mange gode samtaler om språk og grammatikk som oppsto da vi veiledet studentenes arbeid. Vi undret oss og utforsket sammen, og viste i denne forbindelse vår respekt for studentenes poenger og undring. Hverken jeg eller min kollega har som nevnt ferdigheter i sørsamisk språk, og vi brukte denne mangelen til å innta en rolle som ikke-eksperter uten fasitsvar. Som språkvitere kunne vi imidlertid veilede og støtte utforskende samtaler om det sørsamiske språket og om språk generelt. Det er imidlertid ingen tvil om at en samiskkyndig faglærer kunne tilført enda mer verdi til økten. En samiskkyndig faglærer ville i større grad kunne åpne 
studentenes øyne for aspekt ved samisk språkstruktur og kontekstualisere oppdagelsene. Opplegget kan likevel gjennomføres av faglærere uten samiske språkferdigheter dersom de a) er åpne om at de ikke har kompetanse i samisk, og b) bruker den manglende kompetansen til å skape et utforskende fellesskap.

\section{Stillas og mestring}

I forbindelse med oversettelsesarbeidet fikk studentene tre typer stillas: ordboka Nedtedigibaakoeh (u.å.), modellering av oversettelsesarbeidet og støtte fra faglærerne. Vi ser nå på om dette var hensiktsmessige stillas med tanke på at vi ba studentene oversette autentiske sørsamiske sangtekster som ikke er produsert for pedagogiske formål.

Studentenes tilbakemeldinger indikerer at stillasene har kompensert for eventuelle utfordringer knyttet til tekstenes vanskelighetsgrad. Dersom de ikke hadde mestret oppgaven, hadde de neppe opplevd at det var «spennende å oversette ord selv», at det var «gøy å jobbe med samisk tekst», at musikk og kultur var «en fin måte å angripe en tekst på», eller at de hadde fått inspirasjon og ny kunnskap om et tidligere totalt ukjent språk. Den tydeligste indikatoren på at stillasene var passende, er observasjonene våre av at studentene klarte å oversette tekstene. Tekstens vanskelighetsgrad er naturligvis ikke uvesentlig. Under utviklingen av opplegget forsøkte jeg å oversette andre sangtekster som viste seg å inneholde setningskonstruksjoner som jeg selv hadde problemer med å glosse og derfor vurderte til å være for utfordrende. Det studien viser er altså at et opplegg om sørsamisk grammatikk ikke trenger å begrenses til læreboktekster eller andre pedagogiske tekster som kan virke mindre interessante og autentiske, fordi man kan arbeide med forholdsvis utfordrende tekster når stillaset gjør det mulig å mestre oppgaven (jf. Cummins, 2017, s. 57; se også Cummins, 1981).

Det bør likevel bemerkes at en student ga uttrykk for et ønske om «en liten innledning i grunnleggende prinsipper for samisk setningsstruktur og grammatikk». En annen student skrev imidlertid at hun syntes det var «fint å ikke få vite så mye om setningsstrukturen på forhånd, fordi da oppdaget vi det selv og får dermed større forståelse rundt setningsoppbygging fordi vi oppdager det i praksis». Dette oppdagelsesaspektet vil trolig bli borte hvis faglærer gir en introduksjonsforelesning om sørsamisk grammatikk. Noe som derimot kan være aktuelt, er å friske opp noen relevante grammatiske termer og kategorier eller be studentene repetere grammatiske termer som forberedelse til økten.

Det er også aktuelt å drøfte stillaset i forhold til oppgavene som kommer etter oversettelsesarbeidet (se Undervisningsmateriell, 2021). En av oppgavene ber studentene oversette norske setninger til sørsamisk som er veldig lik en setning som figurerer i tekstene (jf. delseksjonen Arbeid med opplegget, og Undervisningsmateriell, 2021). Studentene får deretter i oppgave å finne på flere setninger på sørsamisk med setninger fra tekstene som mal (se oppgave 3 i 'Lærerens ark til Sjamma onne maana' og oppgave 4 i 'Lærerens ark til Stuora várrie’ i Undervisningsmateriell, 2021). Et slikt stillas tilbyr altså en viss grad av valgfrihet: 
Studentene konstruerer sørsamiske setninger som kommuniserer et innhold de selv er med på å bestemme, og stillaset øker sjansen for mestring (jf. Blouwolff, i Blouwolff \& Gonzalez, 2019, og hennes bruk av 'sentence frames'). Studentene i forsøket klarte å konstruere sørsamiske setninger på bakgrunn av malene.

Setningsmaler kan også minke sjansen for å ende opp med grammatisk ukorrekte sørsamiske setninger. Dersom en student vil oversette en selvvalgt, kompleks setning til sørsamisk, så er det risiko for at hun ender opp med en sørsamisk setning som ikke er korrekt. På den andre siden er det interessant å bemerke at man i fremmedspråksundervisningen har gått bort fra ideen om at allting må være pinaktig korrekt (Anja Synnøve Bakken og Helen Murray, personlig kommunikasjon, 2019). Språk handler om å kommunisere, og språkbruk og språklæring blir veldig begrenset hvis vi alltid må tenke på korrekthet. En av oppgavene i oppleggets nåværende form (oppgave 5 i 'Lærerens ark' til begge sangtekstene i Undervisningsmateriell, 2021) går derfor ut på at studentene fritt skal velge setninger som de har lyst til å finne ut hvordan man sier på sørsamisk. Slik får studentene anledning til å prøve seg på setninger på sørsamisk som er relevante for dem å kunne si. Dette er naturligvis mer krevende enn å oversette en setning som er nesten lik en setning man har oversatt før og derfor har en mal for. Oppgaven med å oversette helt valgfrie setninger kommer derfor etter oppgavene som innebærer bruk av setningsmaler.

\section{Oppleggets grammatikkdidaktiske potensial}

Opplegget er primært utviklet for å gi innblikk i sørsamisk språk og tekst. I tillegg ligger det et grammatikkdidaktisk potensial i opplegget som kan styrke studentenes forståelse for grammatikk.

Læringsutbyttet øker når man anvender det man har lært til å løse problemer og oppgaver i nye sammenhenger (Kunnskapsdepartementet, 2015-2016, s. 14). I opplegget om sørsamisk språk og tekst bruker studentene aktivt sin viten om grammatikk (f.eks. bøying og grammatiske kategorier) til å oversette og forstå den sørsamiske teksten. Dette bidrar til en helhetlig forståelse av språk, fordi studentene får oppleve hvordan grammatiske mønstre og realiseringene av disse i tekst er to sider av samme sak. Opplegget realiserer dermed Haugens (2019) anbefaling om at grammatikkundervisning må la studentene se forbindelsen mellom det abstrakte systemet (grammatikken) og faktisk språkbruk for å styrke forståelsen av hvordan de ulike deler av et språkfag henger sammen.

Arbeid med samisk språk er særlig egnet for aktiv bruk av grammatikkkunnskap, fordi denne kunnskapen er desidert nødvendig for å løse oppgavene. Når studenter uten språkferdigheter i samisk skal oversette eller konstruere sørsamiske setninger, så kommer de ikke i mål uten å bruke kunnskap om grammatikk. Hvis de bare oversetter ordene uten å se på bøying, blir oversettelsen av dellie edtjh åeredh til ‘derpå skulle sove’. Denne oversettelsen gir ikke mening, 
fordi den ikke sier noe om hvem som skal sove og når. De må se på hvordan ordene i den samiske teksten er bøyd for å komme frem til en informativ setning. Deres eksisterende kunnskap om grammatikk er altså nødvendig for å løse oppgaven. Videre er bruken av grammatiske termer, altså metaspråket, nødvendig for å kunne samtale og samarbeide om oppgaven. Studentene får dermed øving i og mer fortrolighet med metaspråk når opplegget gjennomføres som et gruppearbeid.

Sist, men ikke minst, åpner opplegget muligheter for å oppøve et sammenliknende blikk på språk, fordi oppgavene ber studentene identifisere likheter og forskjeller mellom norsk og sørsamisk. De oppøver med andre ord både et blikk for og et språk om kontrastiv grammatikk. Dette kan forberede dem på å veilede elever mot kompetansemål knyttet til sammenlikning av språk i læreplaner i norsk (Utdanningsdirektoratet, 2020b, 2020c).

\section{Avslutning}

\section{Konklusjon og implikasjoner}

Læreplan i norsk (Utdanningsdirektoratet, 2020b) og kompetansemålene i norskdidaktikkemner har ikke eksplisitte mål knyttet til samisk språkstruktur. Det er derfor tilfeldig om en norsklærerstudent eller en elev får anledning til å utforske oppbyggingen av et av de samiske språkene som er så nært knyttet til landet de bor i. Artikkelen har presentert og diskutert et opplegg som er utviklet for å la norsklærerstudenter oppleve at sørsamisk språk ikke er utilgjengelig, men et språk som følger et mønster i likhet med andre språk.

Gjennomføringen av opplegget og studentenes tilbakemeldinger viser at a) det er mulig for studenter uten samiske språkferdigheter å lese og oversette en kort, velvalgt og autentisk sørsamisk tekst i løpet av en enkelt undervisningsøkt, og b) opplegget kan gi dem innsikt i og opplevelse av samisk språk på en måte som engasjerer dem. Den online ordboka Nedtedigibaakoeh (u.å.) gjorde det mulig for studentene å oversette autentiske og forholdsvis utfordrende samiske tekster (jf. Cummins, 2017, s. 57; se også Cummins, 1981). Også ungdomsskoleelever kan, ifølge studentenes tilbakemeldinger, muligens ha utbytte av en tilpasset versjon av opplegget.

Oversettelsen og oppgavene krever at studenten dykker ned i grammatikken, og studenten støttes i å lage egne setninger på samisk. Dette gir et fundament for videre utforsking av samisk språk alene eller sammen med elever, fordi studenten har fått innblikk i hvordan språket er bygd opp og erfaring med å bruke Nedtedigibaakoeh. Lesing av en samisk tekst på samisk har dessuten en verdi i seg selv, uansett om studenten (eller eleven) bruker det som fundament for å lære seg mer samisk: Når studenten leser teksten på samisk, får hun i større grad oppleve innholdet via en samiskspråklig mal (jf. Wong \& Solis, 2019).

Opplegget kan også brukes som del av den generelle grammatikkundervisningen. Studentene må anvende kunnskap om grammatiske kategorier aktivt 
når de skal lage sørsamiske setninger; med mindre de har kompetanse i et samisk språk, kan de ikke støtte seg på intuisjon om hva som høres riktig ut. Oversettelsesarbeidet bidrar til en helhetlig forståelse for språk som fenomen, fordi det innebærer å se sammenhengen mellom språksystemet, altså grammatikken, og realiseringer av språksystemet i teksten som to sider av samme sak (Haugen, 2019). Dette legger til rette for en varig forståelse av grammatikkbegrepene, fordi studentene anvender sin grammatikkunnskap til å løse oppgaver i nye sammenhenger (jf. Utdanningsdirektoratet, 2020d; Kunnskapsdepartementet, 2015-2016, s. 14). Sist, men ikke minst, kan opplegget bidra til en opplevelse av at kunnskap om grammatikk er verdifull, fordi denne kunnskapen kan gi innsikt i innholdet i en tekst som man ellers ikke hadde tilgang til, samt innsikt i et språk man ikke hadde kompetanse $\mathrm{i}$.

\section{Forslag til videre forskning og utvikling}

Noen av studentene bemerket at opplegget kan anvendes på ungdomstrinnet. Dette er en spennende tanke som er verdt å forfølge. Arbeidet med å justere, utprøve og evaluere en ungdomsskoleversjon av opplegget kan gjerne gjøres av praktiserende lærere eller lærerstudenter som har en helhetlig innsikt i pedagogikk og grammatikkdidaktikk.

Det er også aktuelt å utforske hvordan opplegget kan inngå i arbeid med samiske stedsnavn på lærerutdanningen eller i skolen (Beret Wicklund, personlig kommunikasjon, 2019). 'Stuora várrie' er for eksempel det store fjellets joik. Med kjennskap til samiske ord for fjell kan man oppdage og kjenne igjen samiske stedsnavn på et kart. Várrie, som figurerer i tittelen, er dessuten umesamisk, mens den sørsamiske sangteksten inneholder det sørsamiske ordet for fjell vaerie (se oppgave 2 i ‘Lærerens ark til Stuora várrie’ i Undervisningsmateriell, 2021). Dette kan gi anledning å oppdage hvilke stedsnavn som er knyttet til hvilke samiske språk, skaffe seg mer kunnskap om sammenhenger mellom språk og geografi og mer kunnskap om Saepmie. ${ }^{11}$ Arbeid med samiske stedsnavn er også aktuelt med tanke på at samiske steder og stedsnavn er forbundet med overlevering av viten, tradisjoner og historisk kunnskap, og med tanke på sammenhengen mellom fornorsking og utelatelse av samiske stedsnavn i kart (NOU, 2016: 18, s. 232). Usynliggjøring av sørsamiske stedsnavn har hatt svært negative konsekvenser for juridisk anerkjennelse av samiske rettigheter til land så sent som på 1990-tallet (se Kolberg, 2017, 2019, s. 134). Dette understreker viktigheten av at generasjonene som vokser opp, har kunnskap om samisk tilstedeværelse, noe de kan få gjennom et opplegg om samisk språk og stedsnavn. ${ }^{12}$

Et tverrfaglig opplegg om samiske stedsnavn er i tråd med kjerneelement som 'Samfunnskritisk tenking og samanhengar' i samfunnsfag som legger vekt på at

\footnotetext{
${ }^{11}$ En aktuell ressurs er Sissel Berghs arbeider som blant annet tar for seg samisk synlighet i Trøndelag (se Bergh, u.å.). Ajmoejimh ajtoejimh (se TSSK, 2020) er et kartarbeid som «leter etter spor av den sørsamiske kulturen blant ord og stedsnavn i landskap, arkeologiske funn og historier fra kysten av Møre, Trøndelag og tilliggende områder». ${ }^{12}$ Se flere ideer til tverrfaglig arbeid med samiske tematikker i Murray (2020).
} 
«[e]levane skal forstå samanhengar mellom geografiske, historiske og notidige forhold og korleis desse forholda kvar for seg og saman har påverka og påverkar menneske og samfunn» (Utdanningsdirektoratet, 2020e, s. 2). Merk at kjerneelementet ikke nevner urfolkstematikk eksplisitt. Dersom man inkluderer urfolkstematikk i arbeidet med kjerneelement og læringsmål som ikke eksplisitt handler om urfolk, kan man bidra til at samiske perspektiv blir en naturlig del av temaene man gjennomgår i løpet av et skoleår i stedet for å være noe man behandler sporadisk og isolert for å nå et eksplisitt læringsmål (Murray, 2020).

\section{Takk}

Mange takk til Helen Murray, Beret Wicklund og Stine H. Bang Svendsen fra forskningsgruppen Indigenous Topics in Education på NTNU og til deltakerne på Undervisningsfaglig forum på Fagseksjon for norsk for konstruktive og stimulerende tilbakemeldinger på artikkelen og utviklingen av undervisningsopplegget. Også en stor takk til to anonyme fagfeller og Acta Didactica Nordens områderedaktør, Åsa af Geijerstam, for nyttige tilbakemeldinger, og til Torgeir Onstad for korrektur og innspill.

\section{Om forfatteren}

Signe Rix Berthelin er førsteamanuensis i norsk språk ved NTNU. Hun har doktorgrad i lingvistikk, og hennes forskningsinteresser er samiske tema i norskdidaktikken, flerspråklighet, transspråking, kreative metaforer og semantikk og pragmatikk. Berthelin er opprinnelig fra Danmark og bosatt i Norge siden 2006. Institusjonstilhørighet: Institutt for lærerutdanning, NTNU, 7491 Trondheim, Norge.

E-post: signe.rix.berthelin@ntnu.no 


\section{Referanser}

Bergh, S. M. (u.å.). Sissel M. Bergh - Incorporated \& Unlimited. http://sisselmbergh.net/ Blichfeldt, B. \& Heggem, T. G. (2014). Nye Kontekst 8-10, Basisbok. Gyldendal.

Blouwolff, R. \& Gonzalez, J. (2019). How World Language Teaching Has Evolved [Podcast episode]. I J. Gonzalez (produsent), Cult of pedagogy, www.cultofpedagogy.com, sept. 2019. Transkripsjon er tilgjengelig på https://www.cultofpedagogy.com/pod/episode-131/

Bottenvann, R. (2017). Å utvikle grunnskolelærarstudentane sin skrivekompetanse. Uniped, 40(4), 312-324. https://doi.org/10.18261/issn.1893-8981-2017-04-04

Bull, E. H. (1997). Sjamma onne maana. Laavlomh maanide [CD]. Idut.

Cummins, J. (1981). The role of primary language development in promoting educational success for language minority students. I C. F. Leyba (red.), Schooling and language minority students: A theoretical framework (s. 3-49). Evaluation, Dissemination and Assessement Center, California State University Los Angeles. https://doi.org/10.13140/2.1.1334.9449

Cummins, J. (2017). Flerspråkiga elever. Effektiv undervisning i en utmanande tid. Stockholm: Natur och kultur.

Gjerpe, K. K. (2017). Samisk læreplanverk - en symbolsk forpliktelse? En begrepsanalyse av det samiske innholdet i Læreplanverket Kunnskapsløftet og Kunnskapsløftet Samisk. Nordic Studies in Education, 37(3-4), 150-165. https://doi.org/10.18261/issn.1891-59492017-03-04-03

Haugen, T. A. (2019). Funksjonell grammatikk som metaspråk i skulen - ei moglegheit for djupnelæring i arbeid med språk og tekst. Acta Didactica Norge, 13(1), Art. 9. https://doi.org/10.5617/adno.6240

Holmen, S. E. (2014). Kvalitet i grammatikkundervisningen i lærerutdanningen. I J. Amdam, $\varnothing$. Helgesen \& K.-W. Sæther (red.), Det mangfaldige kvalitetsomgrepet. Fjordantologien 2013 (s. 83-100). Forlag 1.

Iversen, H. M., Otnes, H. \& Solem, M. S. (2011). Grammatikken i bruk. Oslo: Cappelen Damm akademisk.

Kolberg, A. (2017). Dr. Yngvar Nielsen - helt eller skurk? I grenseland - sørsamisk i MidtNorge. https://blogg.forskning.no/i-grenseland-sorsamisk-i-midt-norge/dr-yngvar-nielsen-helt-eller-skurk/1097863

Kolberg, A. (2019). The Indigenous Voice in Majority Media. South Saami Representations in Norwegian Regional Press 1880-1990. I H. Hermanstrand, A. Kolberg, T. R. Nilssen \& L. Sem (red.), The Indigenous Identity of the South Saami - Historical and Political Perspectives on a Minority within a Minority (s. 121-149). Springer. https://link.springer.com/book/10.1007/978-3-030-05029-0

Kunnskapsdepartementet (2015-2016). Fag - Fordypning - Forståelse: En fornyelse av Kunnskapsløftet. Meld. St. 28 (2015-2016). https://www.regjeringen.no/contentassets/e8e1f41732ca4a64b003fca213ae663b/no/pdfs/s tm201520160028000dddpdfs.pdf

Laake, S. \& Eiesland, E. A. (2019). Lærere og grammatikkundervisning. Møte om norsk språk - MONS 18; 2019-11-26-2019-11-29. NTNU Trondheim.

Magga, O. H. \& Magga, L. (2012). Sørsamisk grammatikk. Davvi girji.

Mikkelsen, M. E. (2019). For utvikling av det samiske samfunnet og den samiske skolen. Ságat. https://www.sagat.no/for-utvikling-av-det-samiske-samfunnet-og-den-samiskeskolen/19.19478

Mortensson, M. (2017). Stuora várrie. Aarehgïjre [CD]. Transjoik Studio v/Fjellheim.

Mortensson, M. (u.å.). Lyrics. http://www.marjamortensson.no/lyrics 
Murray, H. M. (2020). Urfolksperspektiver i fagfornyelsen - nye læreplaner krever fornyelse i undervisning om urfolk. Bedre skole. https://www.utdanningsnytt.no/fagartikkelfagfornyelse-laereplaner/urfolksperspektiver-i-fagfornyelsen/238509

Nedtedigibaakoeh (u.å.). Sørsamisk-norsk-sørsamisk ordbok. Giellatekno, UiT Norges arktiske universitet. https://baakoeh.oahpa.no

Ngai, P., Bæk, U.-B. K. \& Paulgaard, G. (2015). Indigenous Education in the Norwegian and U.S. Contexts. I K. W. Shanley \& B. Evjen (red.), Mapping Indigenous Presence. North Scandinavian and North American Perspectives (s. 91-132). Arizona University Press.

NOU 2016: 18. Hjertespråket - Forslag til lovverk, tiltak og ordninger for samiske språk. Departementenes sikkerhets- og serviceorganisasjon, Informasjonsforvaltning. https://www.regjeringen.no/contentassets/ad82d773c3094582a2660908b48886d3/no/pdfs /nou201620160018000dddpdfs.pdf

NRK (2013, 21. november). Kampen for språket [Videoklipp]. Den stille kampen. https://tv.nrk.no/serie/den-stille-kampen/sesong/1/episode/4/avspiller

Olsen, T. A., Sollid, H. \& Johansen, Å. M. (2017). Kunnskap om samiske forhold som integrert del av lærerutdanningene. Acta Didactica Norge, 11(2), Art. 5. https://doi.org/10.5617/adno.4353

Opplæringsloven (1998). Innhaldet i opplæringa (§6-4). Lov om grunnskolen og den vidaregåande oppleringa (oppleringslova) (LOV-1998-07-17-61). https://lovdata.no/dokument/NL/lov/1998-07-17-61/KAPITTEL_4\#shareModal

Rammeplan ALU (2003). Rammeplan for allmennlærerutdanningen 2003. https://www.regjeringen.no/globalassets/upload/kd/vedlegg/uh/rammeplaner/larer/ramme planalu2009.pdf

Refsahl, V. (2007). Når lesing er vanskelig - i videregående skole. I E. K. Vold \& V. Saltveit (red.), Vi har prøvd alt! Systemblikk på pedagogiske utfordringer. En artikkelsamling om tilpasset opplæring, inkludering og atferd i skolen (s. 181-206). Lillegården kompetansesenter, Bredtvet kompetansesenter og Trøndelag kompetansesenter, Porsgrunn.

Regjeringen (2018). Hvilke rettigheter har du? Kommunal- og moderniseringsdepartementet. https://www.regjeringen.no/no/tema/urfolk-og-minoriteter/samepolitikk/samiskesprak/hvilke-rettigheter-har-du/id633145/\#2

Ryan, R. M. \& Deci, E. L. (2000). Intrinsic and Extrinsic Motivations: Classic Definitions and New Directions. Contemporary Educational Psychology, 25(1), 54-67. https://doi.org/10.1006/ceps.1999.1020

Sametinget (u.å.). Laavlomegcrjetje Saemesth maanine [Sanghefte Snakk samisk med barnet].

https://www.trondheim.kommune.no/contentassets/191b8037542a493d84cace0f1c4ceeca/ sanghefte-snakk-samisk-med-barne.pdf

Steinfjell, R. B. (2014). “Taking our language back home” - Motivation and challenges in the South Sami area. Masteroppgave, Senter for samiske studier, UiT - Norges arktiske universitet. https://munin.uit.no/bitstream/handle/10037/7087/thesis.pdf? sequence=2\&isAllowed=y

Talleraas, G. (2019). Kompetanseutvikling i store grupper: Refleksjon omkring ulike læringsaktiviteter. I S. Loeng, B. P. Mørkved \& B. S. Isachsen (red.), Studentaktiv læering - praksisncer undervisning i høyere utdanning (s. 165-200). Cappelen Damm Akademisk. TSSK - Trøndelag senter for samtidskunst (2020). Ajmoejimh ajtoejimh - Sissel M Bergh. http://www.samtidskunst.no/event/sissel-m-bergh-ajmoejimh-ajtoejimh/

Undervisningsmateriell (2021). https://srixberthelin.wixsite.com/tilundervisning

Utdanningsdirektoratet (2020a). Overordnet del - Identitet og kulturelt mangfold. https://www.udir.no/lk20/overordnet-del/opplaringens-verdigrunnlag/1.2-identitet-ogkulturelt-mangfold/ 
Utdanningsdirektoratet (2020b). Lœreplan i norsk (NOR01-06). https://www.udir.no/lk20/nor01-06

Utdanningsdirektoratet (2020c). Lcereplan i grunnleggende norsk for språklige minoriteter (NOR07-02). https://www.udir.no/lk20/nor07-02

Utdanningsdirektoratet (2020d). Dybdelcring. https://www.udir.no/laring-ogtrivsel/dybdelaring/

Utdanningsdirektoratet (2020e). Læreplan i samfunnsfag (SAF01-04). https://www.udir.no/lk20/saf01-04

Wong, K. L. \& Solis, R. D. K. (2019). Ka unuhi a me ka ho'okē: A Critique of Translation in a Language Revitalization Context. I E. A. McKinley \& L. Tuhiwai Smith (red.), Handbook of Indigenous Education (s. 529-544). Springer. https://doi.org/10.1007/978981-10-3899-0_19

Wood, D., Bruner, J. S. \& Ross, G. (1976). The role of tutoring in problem solving. The Journal of Child Psychology and Psychiatry, 17(2), 89-100.

https://doi.org/10.1111/j.1469-7610.1976.tb00381.x 